\title{
Reservoir Characterization and Pore Type Systems of Carbonate Low Resistivity Pay in Persian Gulf
}

\author{
Bita Arbab, Davod Jahani, Bahram Movahed \\ Department of Geology, Basic Science Faculty, North Tehran Branch, Islamic Azad University, Tehran, Iran \\ Email:bitaarbab@yahoo.com,d_jahani@iau-tnb.ac.ir,movahed@capegroup.org
}

How to cite this paper: Arbab, B., Jahani, D. and Movahed, B. (2017) Reservoir Characterization and Pore Type Systems of Carbonate Low Resistivity Pay in Persian Gulf. Open Journal of Geology, 7, 859-870. https://doi.org/10.4236/ojg.2017.76059

Received: March 24, 2017

Accepted: June 27, 2017

Published: June 30, 2017

Copyright $\odot 2017$ by authors and Scientific Research Publishing Inc. This work is licensed under the Creative Commons Attribution International License (CC BY 4.0).

http://creativecommons.org/licenses/by/4.0/

(c) (i) Open Access

\begin{abstract}
The main focus of study is to characterize lower and upper cretaceous carbonate deposits with Low Resistivity Pay, in Persian Gulf. Four oil reservoirs in the Cretaceous including the Zubair, Buwaib, Shuaiba and Khatiyah Formations of Southern fields have been analyzed. Here is a look at that to determine main factors on decreasing resistivity in pay zone. In some intervals resistivity responses reach less than 6 to $1 \mathrm{ohm} \cdot \mathrm{m}$. Significant hydrocarbon accumulations are "hidden" in low resistivity Pay zone, (LRPZ). LRPZ reservoirs have been found in some formations in Persian Gulf. Causes of LRPZ reservoirs on the basis of experimental analysis include clay-coated grains, carbonate with interstitial dispersed clay. On the other side Smectite and Kaolinite of main clays types have high CEC and greater impact on lowering resistivity. Micritization and Pyritization of digenetic process have noticeable impact on LRPZ. It is mentioned that Lønøy method applied to address pore throat sizes which contain Inter crystalline porosity, Chalky Limestone, Mudstone micro porosity. Pore systems are classified at class 2 and 3 Lucia and pore size varies from 0.5 to 4 micron. NMR Core and Log results show different pore size distribution. NMR core and MRIL results explain that decreasing of resistivity in pay zone is related to texture and grain size variation not being existence of moved water. Irreducible water estimate for this reservoir was between $30 \%$ and $50 \%$. T2 cut off estimates, for defining irreducible water saturation, $115 \mathrm{~ms}$.
\end{abstract}

\section{Keywords}

Clay Types, CEC, Micritization, Low Resistivity Pay Zone, Lucia, Lønøy Method, NMR, Pore Size and Irreducible Water

\section{Introduction}

This paper discusses the causes and location of LRLC pay zones, summarizes 
some of LRPZ examples. The examples are from Wells data of Balal, Salman and Reshadat fields from southern of Persian Gulf. Khatiyah (Cenomanian), Shuaiba (Aptian), Zubair and Buawib (Barreminan) formations have been selected for reservoir studying. The reservoir characterization of low resistivity pay has been challenging due to high reservoir heterogeneity [1]. The pay zone includes carbonate reservoirs that resistivity logs have a resistivity between 6 to $1 \mathrm{ohm}$-meters and even in some intervals reach less than $1 \mathrm{ohm} \cdot \mathrm{m}$. Due to influence of digenetic effects, determination of pore type size and pore distribution has significant impact. Current study shows that decreasing resistivity is related to texture changes not having movable water. In addition, the type of clay has a main role on resistivity response. Smectite is main clay types of mentioned formations. Smectite and Montmorillonite have high CEC (cation exchange capacity) and greater impact on lowering resistivity [2]. For each reservoirs microfacies analysis, digenetic process, rock fabric and pore systems have been defined.

\section{Geological Setting}

In Persian Gulf region the cretaceous succession are normally divided into three distinct parts. At the beginning of the Cretaceous global sea level was relatively high and consequently most of the Basin accumulated almost exclusively shallow-marine carbonates of Tamama group (Figure 1). The Basin was rapidly in filled, first bycarbonates and later by terrigenous clastic of Buwaib, Zubair and

\begin{tabular}{|c|c|c|c|c|c|}
\hline 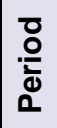 & $\begin{array}{l}\text { 듬 } \\
\text { 늠 }\end{array}$ & $\begin{array}{l}\frac{0}{3} \\
\frac{0}{0}\end{array}$ & $\begin{array}{c}\text { Formation I } \\
\text { Member(Qatar) }\end{array}$ & Discription & $\begin{array}{c}\text { Formation I } \\
\text { Member(Iran) }\end{array}$ \\
\hline \multirow{13}{*}{ 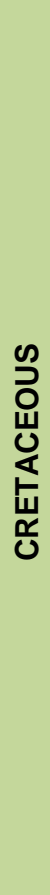 } & \multirow{3}{*}{ 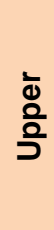 } & \multirow{3}{*}{ 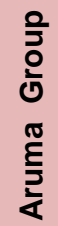 } & Shargi & Chalky Limestone,Marl & Gurpi \\
\hline & & & Halul & Limestone & Ilam \\
\hline & & & Laffan & Shale & \multirow{4}{*}{ Sarvak } \\
\hline & \multirow{4}{*}{$\begin{array}{l}\frac{0}{\overline{0}} \\
\frac{0}{\Sigma}\end{array}$} & \multirow{4}{*}{$\begin{array}{l}00 \\
\frac{0}{7} \\
\frac{0}{0} \\
\pi \\
\frac{0}{\pi} \\
3\end{array}$} & Kahtiyah & Limestone & \\
\hline & & & Ahmadi & Shale & \\
\hline & & & Maddud & Limestone & \\
\hline & & & Nahr Umr & Shale & Kazhdumi \\
\hline & \multirow{6}{*}{ נָ } & \multirow{6}{*}{ 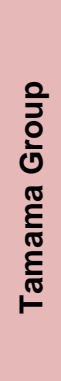 } & Shuaiba & Limestone & Dariyan \\
\hline & & & Zubair & Limestone,Shale & Gadvan \\
\hline & & & Upper Buwaib & Limestone & \multirow{2}{*}{ Upper Fahliyan } \\
\hline & & & Lower Buwaib & Limestone & \\
\hline & & & Yamama & Limestone & \multirow{2}{*}{ Fahliyan } \\
\hline & & & Sulaiy & Limestone,Marl & \\
\hline
\end{tabular}

Figure 1. Stratigraphic column from the lower, middle, upper cretaceous. 
Biyadh formations consequently. The Zubair carbonate (lithostratigraphic equivalents of Gadvan Formation) is considered to have good reservoir potential in Persian Gulf. This formation is one of subordinate reservoir rocks in the Persian Gulf Basin. Buwaib Formation is characterized by inter-bedded porous carbonate and tight argillaceous limestones or marls. The formation is lithostratigraphic equivalent of the Ratawi Formation of Kuwait and Gadvan Formation in Iran [3]. The Buwaib Formation and its equivalents host prolific oil reserves in a number of the Persian Gulf countries, particularly in Saudi Arabia, Kuwait, and UAE [4]. In Iran, the Gadvan Formation forms good oil reservoirs, mainly in the Abadan Plain (e.g., Azadegan, Jufair, Sepehr, and Yadavaran fields), southern Dezful Embayment (Chahar Bisheh, Gulkhari, and Chilingar fields) and northwest of the Persian Gulf (Arash, Soroosh, Nowruz, and Ferdowsi fields). In the Persian Gulf, the Hauterivian reservoirs are known as the Khalij member and Dictioconous carbonates [5].

During middle Aptian carbonate platform were deposited with pellet bioclastic limestone in intershelf deeper water in south and north Persian Gulf in south pars this sediment are Shuaiba (dariyan) reservoir rock in cretaceous. After rising sea level at Aptian carbonate platform extended in early Albian with decline of water sediment extended in open marine as kazhdumi and Burgan. The Aptian carbonates Shuaiba Formation) forms prolific reservoirs in the eastern Persian Gulf, particularly in the UAE. This formation is overlain by the marls and clastics of NahrUmr Formation and underlain by the Kharaib carbonates, in this area. The Algal mounds and rudist buildup facies are the most productive zones, while karstified carbonates in the uppermost parts of the formation are other important oil-bearing intervals in the Shuaiba Formation [4]. In the UAE, the Shuaiba Formation, with thickness ranging from 45 to $145 \mathrm{~m}$, consists of two informal and one formal member: the lower Shuaiba and upper Shuaiba members and the Bab Member, in ascending order. It is characterized as a prograding Orbitolina-dominated platform that surrounded the interior-shelf (Bab Basin) in the offshore of UAE.

During the middle cretaceous in late Albian-Cenomanian time the khatiyah (Sarvak of Iran) inter shelf basin formed in the southern part of Persian Gulf. The khatiyah consists of calcareous shales grading upward into argillaceous plagic lime mudstone with abundant calcisphere and planktonic formainifera. It overlies Maddud formation and locally is equivalent to upper Sarvak formation.

\section{Studying Method}

We use available data such as thin sections, electrical well logs, NMR logs and core data to define quality of reservoir. Fully water saturated plugs were centrifuged in air using small capillary pressure steps, then the saturation profile along the length of the core was imaged using NMR. The NMR profiles clearly displayed a structural heterogeneity which influenced the fluid distribution. Along with additional data from formation pressure and down-Hole fluid sampling analysis were used. For pore size distribution, method Lønøy (2006) has been applied. 


\section{Causes of LRLC Reservoirs}

\subsection{Clay Types}

Clay minerals with their water-filled micro porosity and their ability to exchange cations contained within pore fluids are the most common causes of LRLC reservoirs [6]. Clays, in order of their highest to lowest exchange capacity and therefore their effect on suppression of electrical logs, are Smectite (Kaolinite), mixed-Layer Smectite (Kaolinite), Illite, Montmorillonite. Distribution clay minerals in cross plot Thorium potassium and XRD results (Figure 2, Figure 3 and Table 1). The cause of the low resistivity is the presence of high cation exchange capacity clay minerals, which also have high irreducible water saturation Intervals. It can also be caused by features like Glauconitic pellets and more than 5 percent conductive materials such as pyrite. Digenetic Process like Micritization, emphasis that quality of the reservoir is influenced by various digenetic process such as Micrtization and Pyritization which have noticeable impact on declining resistivity. Porosity varies between interparticle, moldic and mudstone microporosity.

\subsection{Main Digenetic Features on Resistivity Response}

Petrographic evidence indicated that Formation was subjected to different diagenetic processes with variable intensities. This formation has been buried to a

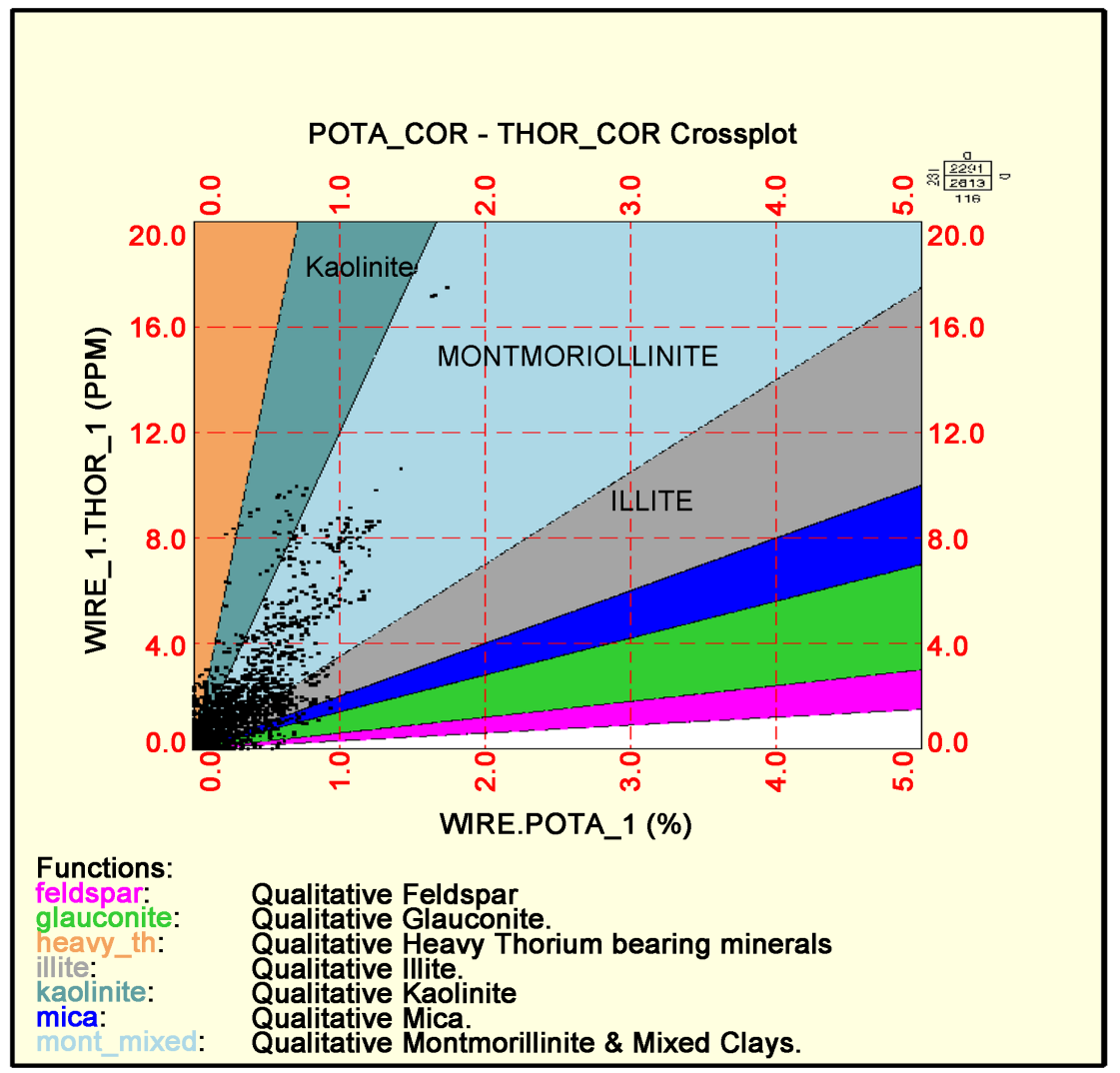

Figure 2. Thorium potassium cross plot for clay types. Plot shows that a type of clay of mixed Illite, Montmorillonite and kaolinite for LRPZ formation. 


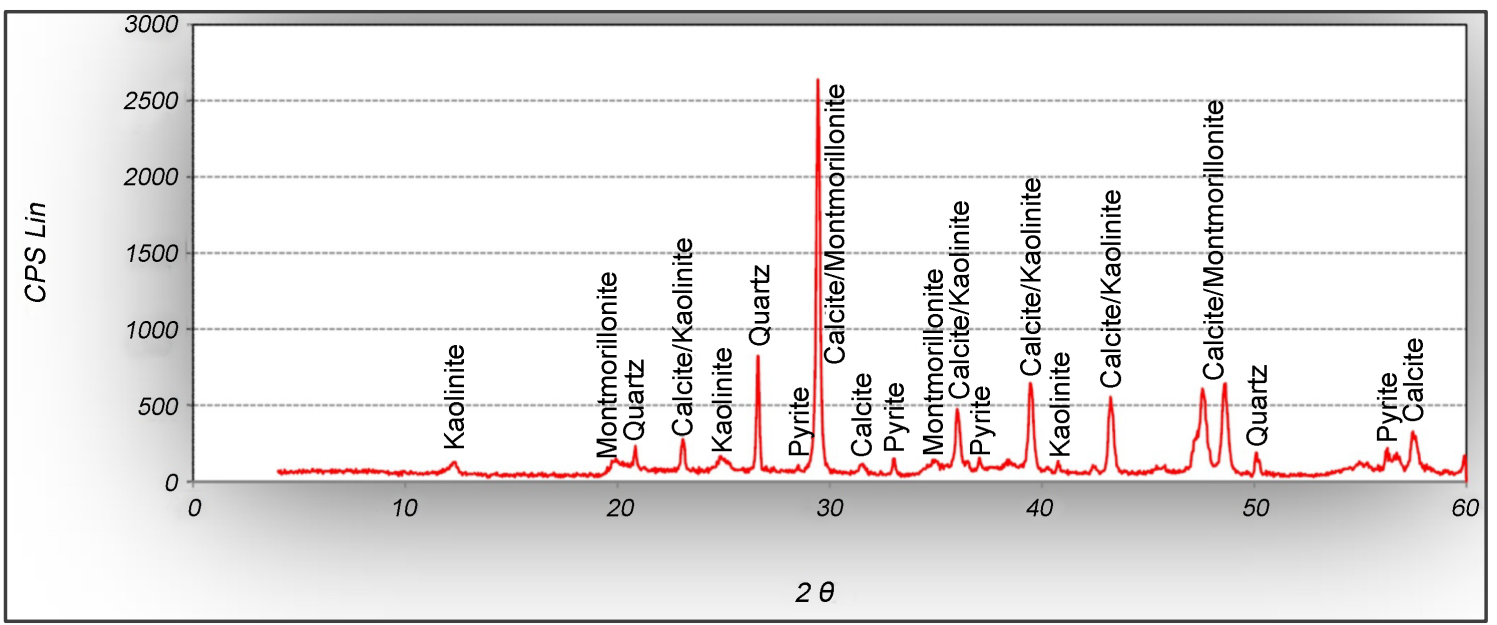

Figure 3. XRD results of core sample data for Buwaib formation.

Table 1. XRD results of Khatiyah formation shows a mixed layer Illite-Smectite is a randomly interstratified type with approximately $60 \%$ Smectite interlayers.

\begin{tabular}{ccccc}
\hline Depth (m) & Plug/Shale & Illite-Smectite & Kaolinite & Chlorite \\
\hline 1317.4 & 4 & 0 & 0 & 0 \\
1321.8 & shale & 23 & 25 & 15 \\
1322.81 & 30 & 26 & 15 & 13 \\
1324.9 & Shale & 31 & 14 & 16 \\
1326.18 & 36 & 39 & trace & 15 \\
\hline
\end{tabular}

depth of more than $2.4 \mathrm{~km}$ (intermediate burial realm) and has experienced micritization, bioturbation, cementation, dissolution and compaction as the main diagenetic alterations.

As an earlier diagenetic process, micritization has affected the carbonate grains in the studied formation (Figure 4(b), Figure 4(c) and Figure 4(e)). Micritized skeletal fragments are very common in the lagoonal and shoal facies (as reworked grains). Some of the uncertain grains (peloids) have formed during the complete micritization. It seems that after deposition, bioclasts were partially or completely micritized by endolithic and other microbes (micro-borer organisms) on the sea floor. This process commonly occurs in relatively low-energy, shallow-marine environments [7] [8]. Pyrite mineralization: Pyrite (FeS2) is present as barrow filling and authigenic diagenetic mineral (scattered opaque minerals both on the bioclasts and in the rock matrix). It occurs as cubic crystals with fine sizes (less than $0.3 \mathrm{~mm}$ ). Pyritization is also seen in the bioclast grains (Figure 4(a), Figure 4(d) and Figure 4(g)). Occurrence of pyrite in organic-rich sediments indicate that this mineral may be formed by sulfate reducing bacteria (SRB), under anaerobic condition, although most of the pyrites in sedimentary rocks are of diagenetic origin [8]. Compaction: On the basis of its burial depth $(>2 \mathrm{~km})$ and evident compaction features, it seems that the Buwaib Formation has affected by compaction with various degrees in shallow to deep burial realms. Compaction features, such as solution seams, stylolites and compaction 

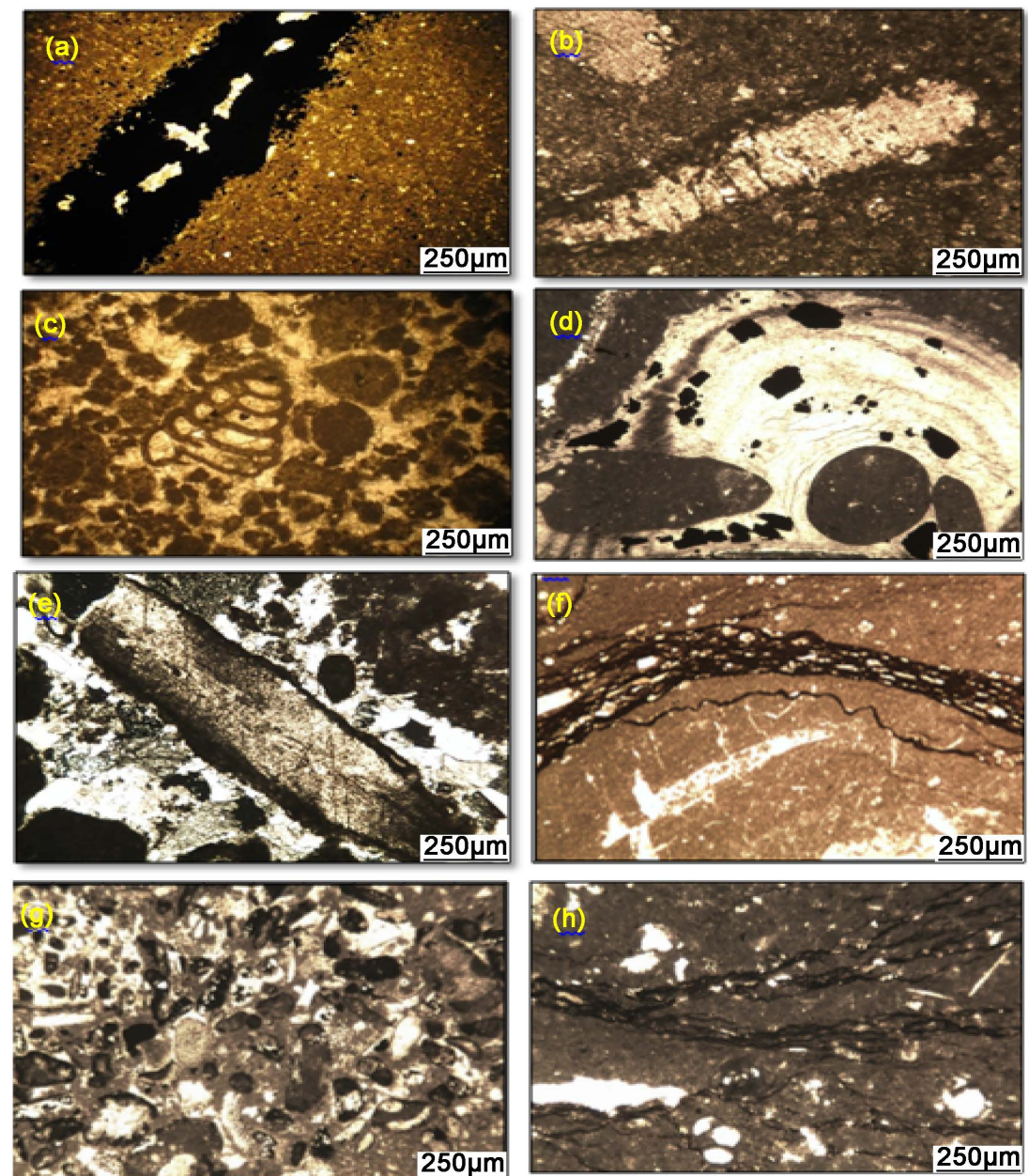

Figure 4. Digenetic features on reservoir carbonate.

gash fractures, are recorded in the both core samples and thin sections of the formation (Figure 4(f) and Figure 4(h)). Our observations have revealed that lithology (particularly clay content) exert the main control on the distribution of stylolite and seam solutions in the studied intervals. Stylolites are very common in the limestone and porous facies, particularly lithocodium-bearing facies, whereas solution seams are commonly seen in the argillaceous limestone facies these features are mostly parallel to the bedding planes. Horse-tail structures are also present. The evidence indicated that main parts of the porosity were destroyed during burial and compaction (and also through cementation). Development of pressure solution features requires a depth of more than $500 \mathrm{~m}$. This process reflects the compaction due to the heavy sedimentary cover $(>1 \mathrm{~km}$ thickness), which indicating burial diagenesis.

\subsection{Pore Type System}

The most widely used pore-type classification systems for carbonate reservoirs are limited by the fact that the relation between porosity and permeability is poorly defined. Existing classification schemes for porosity-permeability data do not, in many cases, optimally integrate sedimentology, diagenesis, and flow-re- 
lated properties. In many carbonate reservoirs, it is therefore difficult to generate predictive models for reservoir-quality distribution, resulting insignificant uncertainty in hydrocarbon reserve calculations. Porosity distribution is a major new element in the classification. Winland and Lucia's subdivision of inter particle porosity has been partly incorporated into the new classification system [9] [10] (Figure 5), but is now based on pore size instead of grain size and sorting. Lønøy method [11] applied to address pore throat sizes which contain Inter crystalline porosity, Chalky Limestone, Mudstone micro porosity. Pore systems are classified at class 2 and 3 Lucia and pore size varies from 0.5 to 4 micron. Pore types, are introduced: mudstone microporosity Interparticle, micromoldic and micromoldic. Mudstone micropores have extremely small pore sizes, commonly a few micrometers in diameter. Individual pores cannot be seen with a standard petrographic microscope.

However, because of the extremely small pore sizes and variable pore structure (interparticle), these pores were classified as a separate pore-type class (Figure 6 and Figure 7). Mudstone microporosity includes both true chalks and chalky microporosity. Chalk micropores are primary in origin and occur between grains of planktonic calcareous algae (coccospheres) or their component crystal plates (coccoliths). Chalky micropores are not related to chalk, but the pore structure is similar [10]. These pores occur between recrystallized mud particles and may be formed either during early meteoric leaching or deeper burial diagenesis. The pores typically form in low-energy, muddy, platform-interior facies.

\subsection{Reservoir Characterization}

Examples of petrophysical evaluation for Khatiyah, Shuiaba and Buawib formations, Mineral responses defines based on petrophysical tools (Table 2). Base on core data and NMR data these formations should be controlled to define precisely water saturation. 2 samples of MICP results for Khatiyah formation show water saturation is $20 \%$ to $45 \%$ (Figure 8 ).

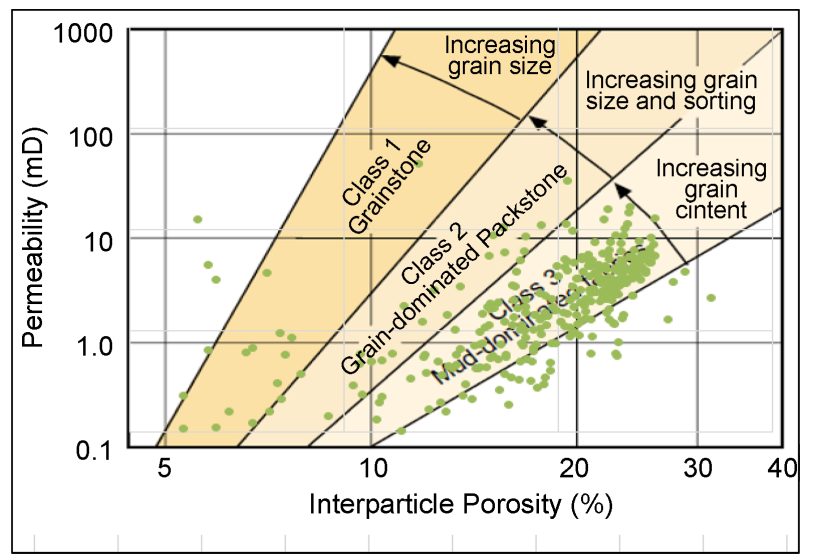

Figure 5. Porosity permeability plots shows with Winland method class 2 and 3 Lucia for reservoirs with low resistivity pay zones. 


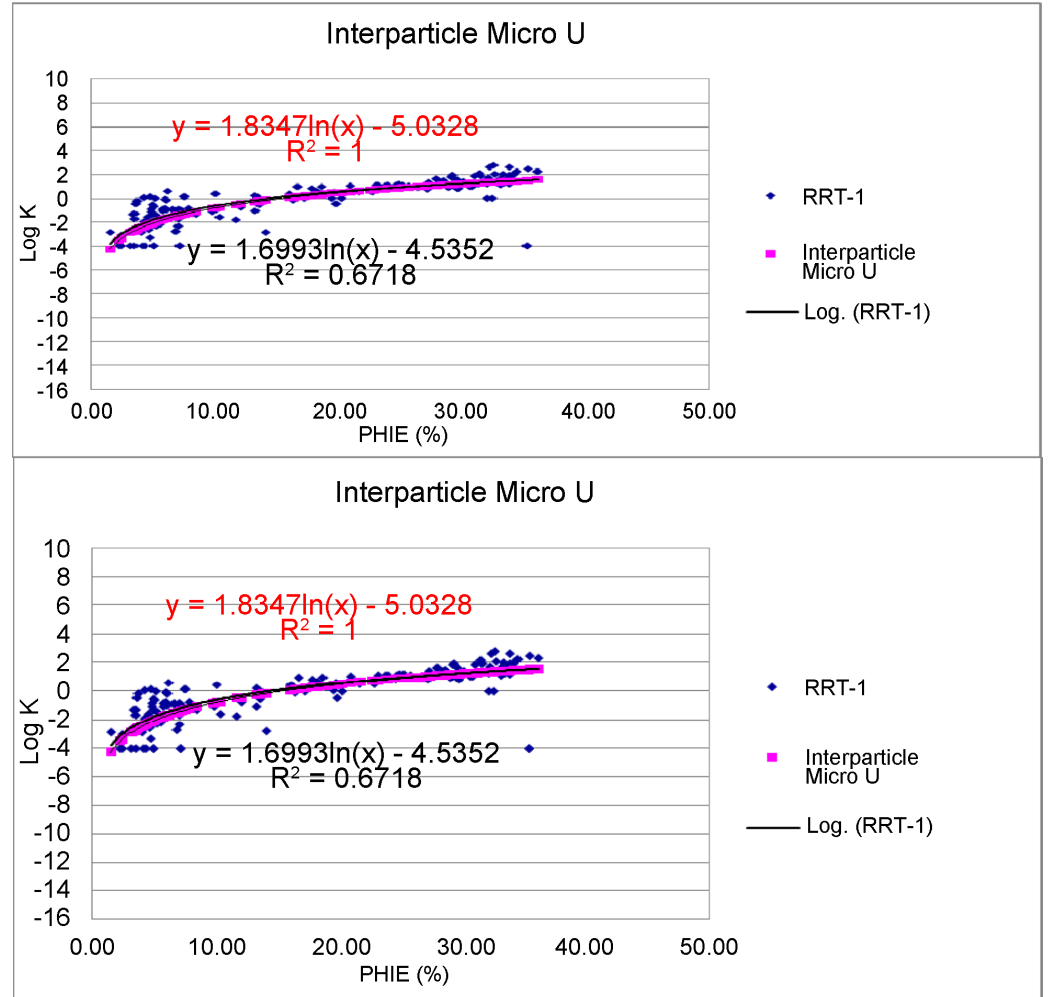

Figure 6. Pore systems of Buwaib formation. Interparticle Lucia 2 and 3 have been defined.

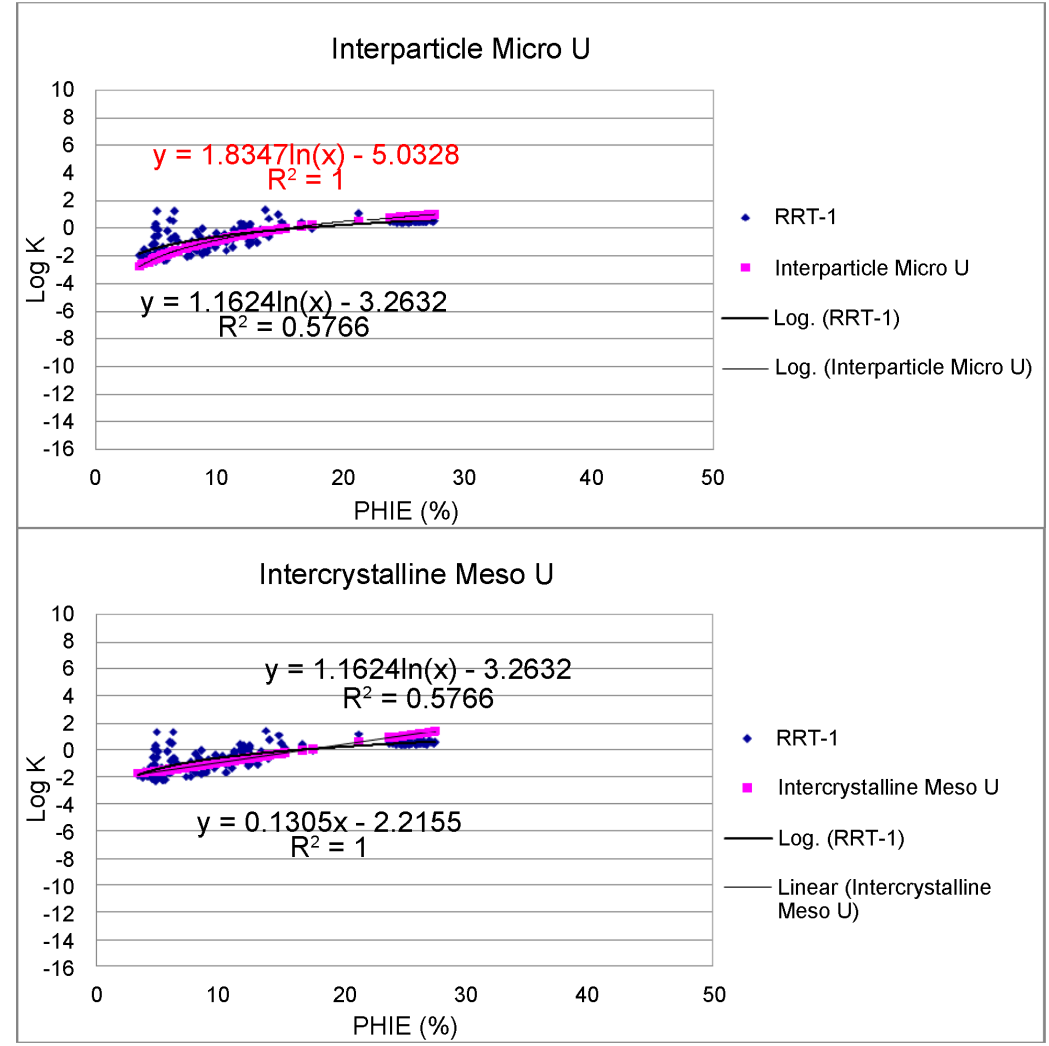

Figure 7. Pore systems of Zubair formation in interparticle microporosity class 3 Lucia. 
Table 2. Real responses for petrophysical evaluation to define precisely porosity and water saturation.

\begin{tabular}{ccccccc}
\hline Mineral responses & RHOB & NPHI & DT & U & CGR & GR \\
\hline Kaolinite (wet clay) & 2.43 & 0.58 & 98 & 4.99 & 100 & 200 \\
Illite (wet clay) & 2.5 & 0.25 & 101.3 & 10 & 150 & 160 \\
Montmoriollinte (wet clay) & 2.2 & 0.45 & 105 & 4 & 150 & 160 \\
\hline
\end{tabular}

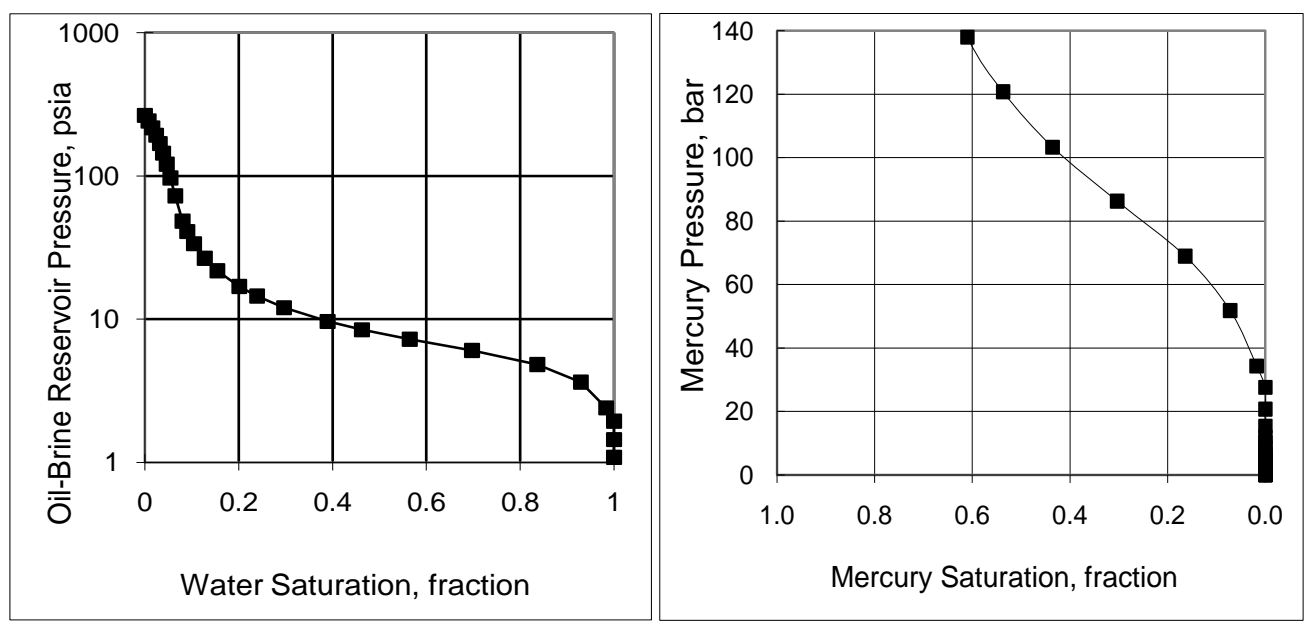

Figure 8. MICP results of LRP show water saturation between 20 to 60 percent.

It should be noted resistivity response these formations are very low (Figure 9 and Figure 10).

Nuclear magnetic resonance (NMR) refers to the response of atomic nuclei to magnetic fields. NMR measurements show pore-size distribution; the presence of clay, vugs; hydrocarbon properties such as viscosity; and grain-size. Knowing the value of T2 cutoff enables the amount of mobile and bound fluids to be calculated from log data. The T2 cutoff is the size boundary between small pores containing bound fluid and larger pores where the fluid is free. While various rock types have standard T2 cutoff values, the geometry of the pores and the rock's mineralogy may shift the T2 spectrum, so laboratory core analysis experiments are used to determine the value of $\mathrm{T} 2$ cutoff.

MRIL (Magnetic Resolution Imager Log) spectrums indicate high volume of irreducible bound water; there is also some free fluid porosity which is mainly water with a little oil in some interval oil and water are identified [12]. Porosity spectrum also show that the total porosity is about $20 \%-25 \%$ in the reservoir intervals as well as permeability varies between 5 to $200 \mathrm{md}$. In order to define water saturation precisely for the reservoir, T2 Cut off define 115 microseconds related to micro porosity carbonate to define. Irreducible water saturation defined $30 \%$ to $50 \%$ in reservoir interval. Combination between full set logs and NMR logs with NMR core results (Figure 10). Water saturation varies between $35 \%$ to $50 \%$ results extract based on 15 core samples selected for NMR analysis in oil brine and air brine condition to get information about pore size Clay bound water, Moved oil and water and residual water saturation. 


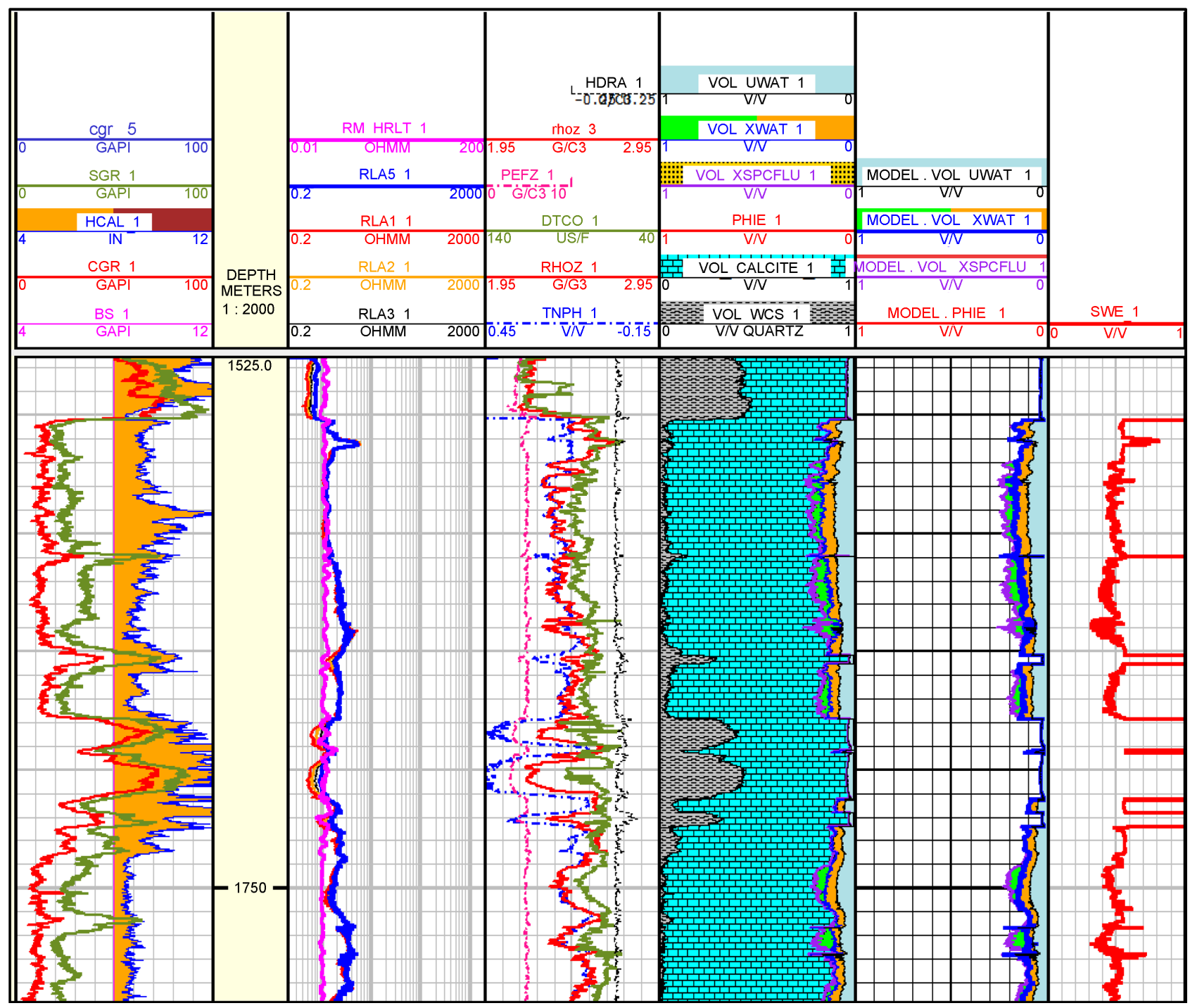

Figure 9. Petrophysical evaluation of Khatiyah formation based on well logs an. Track 1 displays Gamma ray and Caliper, track 2 shows resistivity track 3 for density and neutron response track 4 lithology calculation, track 6 and 7 display fluid calculation. Resistivity is near to $1 \mathrm{ohm}$ meter. Intervals show hydrocarbon Pay zone. Water saturation calibrate with MICP results.

\section{Conclusions}

The lower and upper cretaceous carbonate Formations are of main producing oil carbonates in the Persian Gulf. Four oil reservoirs in the Cretaceous from the Zubair, Buwaib, Shuaiba and Khatiyah formations of Southern fields have susceptible for LRP formations. Majority of the response resistivity logs are between 1 to $6 \mathrm{ohm} \cdot \mathrm{m}$.

Geological core analysis (XRD) and standard petrophysical cross plots show that dispersed clay types and conductive minerals like pyrite are most reason for LRP reservoir. Smectite and Illite are main clay types that Smectite has high CEC (Cation exchange capacity) and greater impact on lowering resistivity.

Petrographic evidence indicated that Formation was subjected to different diagenetic processes with variable intensities. Reservoir quality is under digenetic process such as pyritization, micritization and bioturbation. 


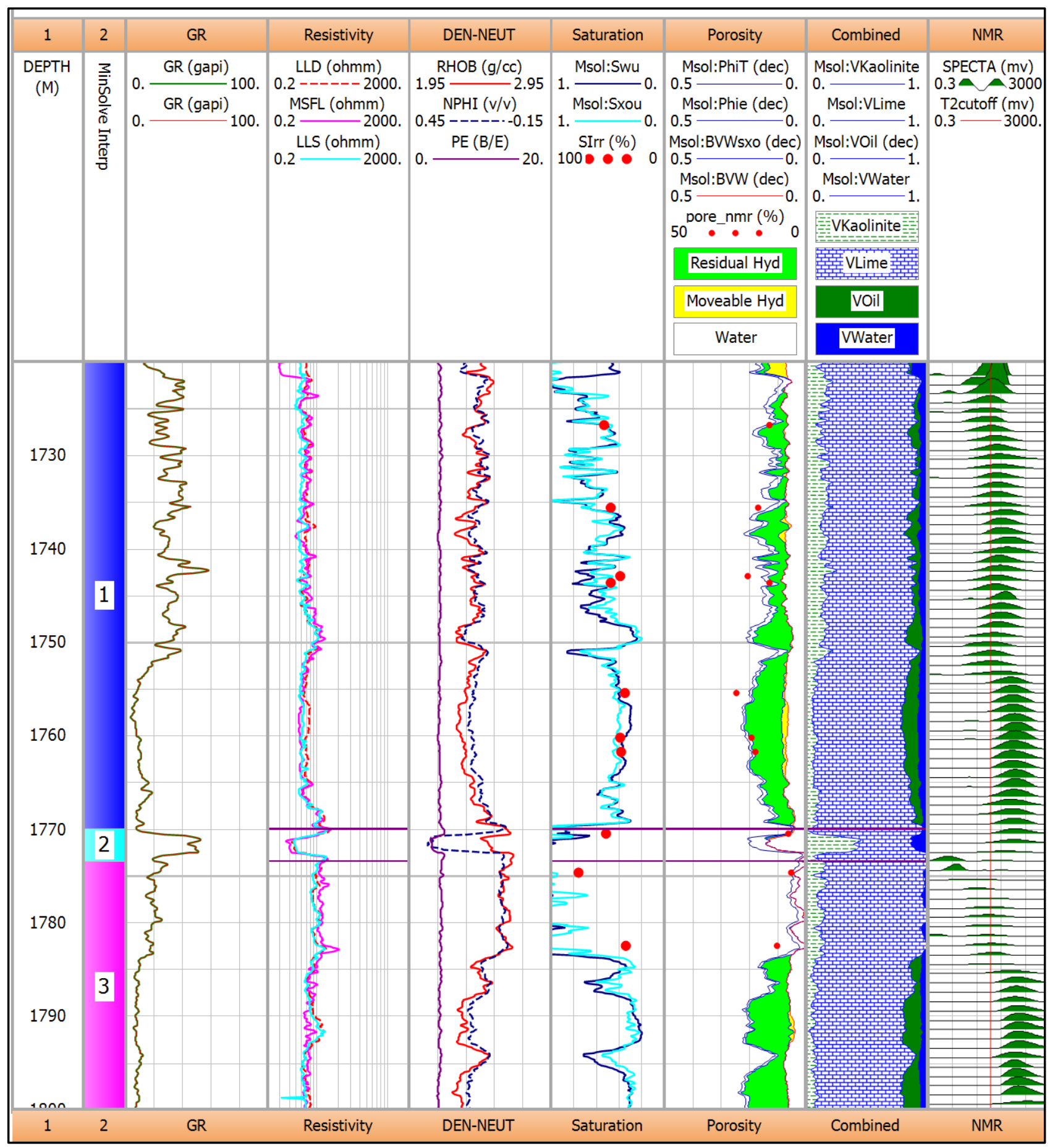

Figure 10. Combination between full set logs and NMR logs with NMR core results. Water saturation varies between $35 \%$ to $50 \%$ results extract based on 15 core samples selected for NMR analysis in oil brine and air brine condition to get information about pore size clay bound water, moved oil and water and residual water saturation.

Lønøy method addresses pore throat sizes which contain Inter crystalline porosity, Chalky Limestone, Mudstone micro porosity. Pore systems are classified at class 2 and 3 Lucia and pore size varies from 0.5 to 4 micron.

MRIL spectrums indicate high volume of irreducible bound water; there is also some free fluid porosity which is mainly water with a little oil; in some inter- 
val oil and water are identified. Porosity spectrums also show that the total porosity is about $20 \%-25 \%$ in the reservoir intervals as well as permeability varies between 5 to $200 \mathrm{md}$. In order to define water saturation precisely for the reservoir, T2 Cut off defines 115 microseconds related to micro porosity carbonate to define.

\section{Acknowledgements}

The authors would like to acknowledge, with deep appreciation and gratitude, invaluable help and give advices of the associate and assistant Professors of Department of Geology, Basic Science Faculty, North Tehran branch, Islamic Azad University, Tehran, Iran. This work is supported by Iranian offshore oil company and Research department that I am so grateful of experts of Iranian Offshore Oil Company for providing required data, and all facilities.

\section{References}

[1] Adedapo, A. and Ayham, A. (2017) A Cohesive Approach at Estimating Water Saturation in a Low-Resistivity Pay Carbonate Reservoir and Its Validation. Journal of Petroleum Exploration and Production Technology, 57, 1-21.

[2] Serra, O.L. (2004) Well Logging. Data Acquisition and Applications, 667.

[3] Sharland, P.R., Archer, R., Casey, D.M., Davies, R.B., Hall, S.H., Heward, A.P., Horbury, A.D. and Simmons, M.D. (2001) Arabian Plate Sequence Stratigraphy. GeoArabia, 2, 1-371.

[4] Alsharhan, A.S. (1985) Depositional Environment, Reservoir Units Evolution, and Hydrocarbon Habitat of Shuaiba Formation, Lower Cretaceous, Abu Dhabi, United Arab Emirates. American Association of Petroleum Geologists Bulletin, 69, 899912. https://doi.org/10.1306/ad462b19-16f7-11d7-8645000102c1865d

[5] Alsharhan, A.S. (2014) Petroleum Systems in the Middle East. In: Rollinson, H.R., Searle, M.P., Abbasi, A.I., Al-Lazki, A.I. and Al Kindi, M.H., Eds., Tectonic Evolution of the Oman Mountains, Vol. 392, Geological Society, London, Special Publications, 361-408. https://doi.org/10.1144/sp392.19

[6] Davis, B. and Flaum, C. (2012) The Lowdown on Low Resistivity Pay: Oilfield Review.

[7] Flügel, E. (2004) Microfacies of Carbonate Rocks: Microfacies of Carbonate Rocks. 976. https://doi.org/10.1007/978-3-662-08726-8

[8] Tucker, M.E. (2001) Sedimentary Petrology. Black Scientific Pub., 260 p.

[9] Winland, D. (2006) Of Amoco, Carbonate Reservoir Characterization. Oil and Gas Business, 2006, 206-217.

[10] Lucia, F.J. (2002) Carbonate Reservoir Characterization. Springer-Verlag, Berlin, $226 \mathrm{p}$.

[11] Lønøy, A. (2006) Making Sense of Carbonate Pore System. AAPG Bulletin, 90, 1381-1405. https://doi.org/10.1306/03130605104

[12] Coates, G.R., Xiao, L.Z. and Prammer, M.G. (1999) NMR Logging Principles and Applications. 232. 
Submit or recommend next manuscript to SCIRP and we will provide best service for you:

Accepting pre-submission inquiries through Email, Facebook, LinkedIn, Twitter, etc. A wide selection of journals (inclusive of 9 subjects, more than 200 journals)

Providing 24-hour high-quality service

User-friendly online submission system

Fair and swift peer-review system

Efficient typesetting and proofreading procedure

Display of the result of downloads and visits, as well as the number of cited articles Maximum dissemination of your research work

Submit your manuscript at: http://papersubmission.scirp.org/

Or contact ojg@scirp.org 